\title{
Presence of T cells directed against CD20-derived peptides in healthy individuals and lymphoma patients
}

\author{
Benoit Milcent ${ }^{1} \cdot$ Nathalie Josseaume $^{1}$ - Quentin Riller ${ }^{1} \cdot$ Ilenia Giglioli ${ }^{1}$. Emilia Rabia ${ }^{1}$. Claire Deligne ${ }^{1}$. \\ Jean-Baptiste Latouche ${ }^{2} \cdot$ Mohamad Hamieh $^{2} \cdot$ Alexandre Couture $^{2}$. Olivier Toutirais ${ }^{3,4} \cdot$ Yu-Chun Lone ${ }^{5}$. \\ Raphaël Jeger-Madiot ${ }^{6}$. Stéphanie Graff-Dubois ${ }^{6} \cdot$ Sandy Amorim $^{7}$. Pascale Loiseau ${ }^{8,9,10}$. Antoine Toubert ${ }^{8,9,10}$. \\ Pauline Brice $^{7}$. Catherine Thieblemont ${ }^{7,11}$. Jean-Luc Teillaud ${ }^{1,12}$. Sophie Sibéril ${ }^{1,13}$ (1)
}

Received: 3 January 2019 / Accepted: 30 August 2019 / Published online: 7 September 2019

(c) The Author(s) 2019

\begin{abstract}
Preclinical and clinical studies have suggested that cancer treatment with antitumor antibodies induces a specific adaptive $\mathrm{T}$ cell response. A central role in this process has been attributed to $\mathrm{CD} 4^{+} \mathrm{T}$ cells, but the relevant $\mathrm{T}$ cell epitopes, mostly derived from non-mutated self-antigens, are largely unknown. In this study, we have characterized human CD20-derived epitopes restricted by HLA-DR1, HLA-DR3, HLA-DR4, and HLA-DR7, and investigated whether T cell responses directed against CD20-derived peptides can be elicited in human HLA-DR-transgenic mice and human samples. Based on in vitro binding assays to recombinant human MHC II molecules and on in vivo immunization assays in $\mathrm{H}-2 \mathrm{KO} / \mathrm{HLA}-\mathrm{A} 2^{+}-\mathrm{DR} 1^{+}$ transgenic mice, we have identified $21 \mathrm{MHC}$ II-restricted long peptides derived from intracellular, membrane, or extracellular domains of the human non-mutated CD20 protein that trigger in vitro IFN- $\gamma$ production by PBMCs and splenocytes from healthy individuals and by PBMCs from follicular lymphoma patients. These CD20-derived MHC II-restricted peptides could serve as a therapeutic tool for improving and/or monitoring anti-CD20 T cell activity in patients treated with rituximab or other anti-CD20 antibodies.
\end{abstract}

Keywords $\mathrm{CD}^{+} \mathrm{T}$ cell responses $\cdot$ Follicular lymphoma $\cdot$ Human CD20-derived peptides $\cdot$ Non-mutated self-peptides

$\begin{array}{ll}\text { Abbreviations } \\ \text { AAPC } & \text { Artificial antigen-presenting cells } \\ \text { CTL } & \text { Cellular Technology Limited } \\ \text { DLBCL } & \text { Diffuse large B cell lymphoma } \\ \text { EFS } & \text { Etablissement Français du Sang } \\ \text { FVIII } & \text { Factor VIII } \\ \text { FL } & \text { Follicular lymphoma } \\ \text { HD } & \text { Healthy donor } \\ \text { KO } & \text { Knock-out } \\ \text { MCL } & \text { Mantle cell lymphoma }\end{array}$

Benoit Milcent and Nathalie Josseaume are first co-authors.

Electronic supplementary material The online version of this article (https://doi.org/10.1007/s00262-019-02389-7) contains supplementary material, which is available to authorized users.

Sophie Sibéril

sophie.siberil@upmc.fr

Extended author information available on the last page of the article

\begin{abstract}
R-CHOP Rituximab, cyclophosphamide, doxorubicin, vincristine, prednisolone

SFU Spot forming units
\end{abstract}

\section{Introduction}

A number of anti-CD20 therapeutic antibodies are now successfully used to treat B cell lymphomas and CLL $[1,2]$. The CD20 membrane-spanning 4A molecule is an unglycosylated phosphoprotein (33-37 kDa, 297 amino acids) encoded by the $M S 4 A 1$ gene and expressed by B cells from the early pre-B cell to the late B cell stages. Pro-B cells do not express CD20. CD20 disappears when B cells differentiate into plasma cells [3-5]. CD20 is involved in the regulation of intracellular calcium levels and in B cell signaling, proliferation, and differentiation [6-9]. It contains two extracellular loops_-one small and one large_containing the epitopes bound by anti-CD20 antibodies [10, 11].

We and others have shown in a mouse model that CD4 ${ }^{+}$ $\mathrm{T}$ cells play a critical role in the long-term antitumor 
protection elicited by anti-CD20 treatment [12-14]. T cell depletion and $\mathrm{T}$ cell transfer experiments demonstrated that anti-CD20 treatment leads to the development of a potent and specific memory $\mathrm{CD} 4^{+} \mathrm{T}$ cell response against $\mathrm{CD} 20^{+}$ tumor cells $[12,14]$. Another study showed that anti-CD20 $\mathrm{mAb}$ engages Fc $\gamma$ RIIA expressed on dendritic cells leading to the priming of self-reactive tumor-specific $\mathrm{CD} 4^{+} \mathrm{T}$ cells [14]. However, the specific $\mathrm{T}$ cell epitopes involved in this process are unknown.

Analyses of the HLA ligandome in healthy donors or patients with B cell malignancies have allowed the identification of self-peptides derived from B cell molecules, in particular CD19 and CD20, that could be recognized by $\mathrm{T}$ cells $[15,16]$. Immunogenic MHC I-restricted CD20derived peptides have also been identified in studies using an in silico approach and in vitro assays based on stimulation of CTLs with candidate peptides [17-21]. Notably, one particular highly immunogenic peptide located in the CD20 transmembrane domain and recognized by $\mathrm{CD} 8^{+}$ T cells, CD20 188-196 (SLFLGILSV), induces the expansion of CTLs in healthy donors and patients. These cells efficiently kill primary tumor cells or cells from cell lines derived from B cell malignancies [17-21]. A strategy developed to detect and expand allo-MHC-restricted T cells reactive to self-tumor antigens has also resulted in the characterization of 20 non-mutated HLA-A*02:01restricted epitopes from CD20 [22]. However, these studies have been largely focused on MHC I-restricted CD20 epitopes. Only one study has reported that a CD20 alternative splicing isoform expressed in patients with $\mathrm{B}$ cell lymphoma can generate immunogenic $\mathrm{CD}^{+}{ }^{+} \mathrm{T}$ cell epitopes [23]. Thus, the identification of MHC II-restricted peptides derived from native non-mutated $\mathrm{CD} 20$ molecule is still needed to better understand the role of $\mathrm{CD} 4^{+} \mathrm{T}$ cells in the long-term response to anti-CD20 treatment.

In this study, we assessed whether human CD20derived MHC II-restricted immunogenic peptides can be identified using a combination of in vitro binding assays to recombinant human MHC II molecules and subsequent in vivo immunization experiments in human HLA-DRtransgenic mice. We could identify a number of CD20derived MHC II-restricted long peptides $(n=21)$ localized in the extracellular, transmembrane and intracellular domains of CD20. These peptides induce in vitro IFN- $\gamma$ responses in PBMCs from healthy donors (HD) and follicular lymphoma (FL) patients.

\section{Materials and methods}

\section{Human samples}

PBMCs from HD were obtained from Cellular Technology Limited (CTL) -Europe $(n=25)$ or from the French blood agency (Etablissement Français du Sang, EFS) $(n=11)$. HD from CTL-Europe were selected as expressing at least one of the following HLA-DR alleles: HLA-DRB1*01:01, HLADRB1*03:01, HLA-DRB 1*04:01, and HLA-DRB1*07:01. Anonymous HD from EFS were not HLA-typed. PBMCs were also obtained from patients diagnosed with high tumor-burden follicular lymphoma (FL; $n=9)$ and treated with a regimen consisting of rituximab combined with chemotherapy (cyclophosphamide, doxorubicin, vincristine, prednisolone) (R-CHOP) (Hemato-oncology Department, Saint Louis hospital, Paris, France). Blood samples from patients were collected 6 weeks after initiation of treatment. HLA typing of patients was performed using the Polymerase Chain Reaction-Sequence Specific Oligoprobe (PCR-SSO) molecular method using the LABType SSO kits from One Lambda Inc. (Canoga). Spleens $(n=7)$ were obtained from organ transplant donors at the Hôpital PitiéSalpêtrière (Paris, France).

\section{Mice}

For immunization, 8- to 12-week-old HLA-A2.1-/ HLA-DR1-transgenic H-2 class I-/class II-knockout (KO) female mice were used [24].

\section{Definition of MHC II-restricted human CD20-derived candidate peptides}

Bioinformatics tools for epitope prediction (SYFPEITHI; IEDB; BIMAS) applied to the human CD20 sequence deposited in the NCBI database (NP_068769.2) were used to identify MHC II-restricted CD20-derived candidate peptides. The candidate peptides were then screened at ProImmune for high MHC-peptide binding scores with the high-throughput ProImmune REVEAL ${ }^{\circledR}$ MHC-peptide binding assay (https://www.proimmune.com/ecommerce/ page.php?page $=$ reveal_class 2 ). This binding assay quantifies the ability of test peptides to bind to the human MHC II molecules HLA-DR1 (allele HLA-DRB1*01:01), HLADR3 (allele HLA-DRB1*03:01), HLA-DR4 (allele HLADRB1*04:01), and HLA-DR7 (allele HLA-DRB1*07:01), and also measures the ability of the bound peptide to stabilize the resulting MHC II-peptide complex. The assay is based on determining the presence or absence of the native conformation of the MHC II-peptide complex, as recognized 
by a specific antibody. Each peptide is given a score relative to a positive control peptide, which is known to bind MHC II molecules with high affinity.

\section{Immunization of mice}

Ten 8- to 12-week-old HLA-A2.1-/HLA-DR1-transgenic female mice (HLA-DRB $1 * 01: 01)$ were intravenously injected with $2 \times 10^{5}$ EL4 mouse thymoma cells expressing human CD20 (EL4-huCD20) [25]. Splenic CD4 ${ }^{+} \mathrm{T}$ cells from these immunized mice were isolated 21 days after injection using the $\mathrm{CD} 4^{+} \mathrm{T}$ cell negative selection kit (Miltenyi Biotec) and pooled. The purified pooled $\mathrm{CD} 4^{+} \mathrm{T}$ cells $\left(10^{5}\right.$ cells/well) were then incubated in ELISPOT plates for $36 \mathrm{~h}$ with $10^{4}$ HLA-DRB $1 * 01$ :01-expressing artificial antigen-presenting cells (AAPCs) derived from NIH-3T3 cells [26] which were loaded with the CD20-derived peptide mixture.

\section{ELISPOT assays}

Human PBMCs ( $n=26$ for HD and $n=9$ for FL patients) or spleen cells $(n=7)\left(2 \times 10^{6}\right.$ cells $\left./ \mathrm{ml}\right)$ were cultured for 7 days in RPMI1640 medium supplemented with $10 \%$ heatinactivated human serum, $1 \%$ L-glutamine, $1 \%$ penicillin, and streptomycin (Life Technologies) in the presence of CD20-derived peptide mixture (10 $\mu \mathrm{g}$ of each peptide). A pool of two human MHC II-restricted Factor VIII (FVIII)derived peptides (peptide 1972, KMALYNLYPGVFETV, and peptide 2145, IARYIRLHPTHYSIR) was used as a control of self-antigen-derived peptides that bind to human HLA-DR molecules [27-29]. In some experiments, $10 \mu \mathrm{g} /$ $\mathrm{ml}$ of blocking anti-HLA-DR, DP, DQ monoclonal antibody (clone Tu39; BD Biosciences) were added to the culture. On day 1, $50 \mathrm{ng} / \mathrm{ml} \mathrm{IL-7} \mathrm{(Peprotech)} \mathrm{and} \mathrm{on} \mathrm{day} \mathrm{3,} 50 \mathrm{UI} / \mathrm{ml}$ IL-2 (Peprotech) were added to the culture. On day 7, $10^{5}$ PBMCs or splenocytes/well were incubated in IFN- $\gamma$ ELISPOT plates (CTL-Europe) for $36 \mathrm{~h}$ in serum-free medium with FVIII- or CD20-derived peptides, in the presence or absence of anti-HLA-DR, -DP, -DQ blocking antibody. Each sample was tested in triplicate and the mean value of each triplicate was reported. The positive threshold was set at $\geq 10 \mathrm{SFU}$ per $10^{5}$ cells after subtracting the background noise, as described previously [30]. In other experiments, $5 \times 10^{5} \mathrm{PBMCs} /$ well from HD $(n=10)$ were tested ex vivo in the absence of cytokines with either the peptide pool (containing $10 \mu \mathrm{g}$ of each peptide) or with each of the 21 peptides $(10 \mu \mathrm{g})(1$ well/peptide or peptide pool). Human and mouse IFN- $\gamma$ ELISPOT assays were performed with the Single Color ELISPOT kit according to the manufacturer's recommendations (CTL-Europe). Following completion of the ELISPOT protocol, the plates were air dried in a laminar flow hood prior to analysis. The resulting spots were counted using a computer-assisted ELISPOT image analyzer (S6 Ultra-V Analyzer, CTL-Europe) customized for analyzing ELISPOT assays to meet the objective criteria for size, chromatic density, shape, and color. Spot forming units (SFU) were automatically calculated by the Immunospot SC Suite Software (CTL-Europe) using the SmartCount ${ }^{\mathrm{TM}}$ and Autogate ${ }^{\mathrm{TM}}$ functions.

\section{Statistical analyses}

Statistical evaluation of mouse and human ELISPOT data was performed using non-parametric paired (Wilcoxon) or unpaired (Mann-Whitney) tests, and multiple $t$ tests with Bonferroni correction (indicated in each figure legend). Prism software (version 5, Graphpad, San Diego, CA, USA) was used for statistical analyses. For all statistical tests performed, $p$ values were considered significant if $\leq 0.05$.

\section{Results}

\section{CD20-derived peptides that bind strongly to human MHC II are immunogenic in HLA-DR transgenic mice}

Using the ProImmune REVEAL ${ }^{\circledR}$ MHC-peptide binding assay, we assessed the binding of 95 overlapping 15 -mer human CD20-derived peptides with an offset of 3 amino acids to recombinant human MHC II molecules frequently found in European populations (HLA-DRB $1 * 01: 01$; HLADRB1*03:01; HLA-DRB 1*04:01; HLA-DRB1*07:01). Six of these peptides failed in synthesis, and therefore could not be tested. The binding assays revealed frames of densely packed high-scoring peptides (Fig. 1a), and thus clusters of potentially immunogenic epitopes within the intracellular, transmembrane, and extracellular domains of the human CD20 molecule (Fig. 1b).

We then assessed whether peptides corresponding to these clusters defined in vitro might be presented by MHC molecules and promote $\mathrm{T}$ cell responses in vivo. $\mathrm{H}-2 \mathrm{KO} /$ HLA-A $2^{+}$-DR $1^{+}$transgenic mice were i.v. injected with $2 \times 10^{5}$ tumor cells expressing the entire human CD20 molecule (EL4-huCD20). 21 days later, splenic CD4 ${ }^{+} \mathrm{T}$ cells were isolated and co-cultured in ELISPOT plates for $36 \mathrm{~h}$ with NIH/3T3 cell-derived AAPCs. These cells that express human HLA-DRB $1 * 01: 01$ molecules loaded with 9 different mixtures of 18 to 20-mer MHCII-restricted peptides selected for their different high-scoring frames (huMHC II_Mix 1 to 9) (Fig. 1; Supplementary Table 1). ELISPOT assays showed that five mixtures of MHC IIrestricted huCD20-derived peptides (huMHC II_Mix 1, huMHC II_Mix 2, huMHC II_Mix 4, huMHC II_Mix 5, and huMHC II_Mix 8) were able to stimulate IFN- $\gamma$ production by $\mathrm{CD}^{+} \mathrm{T}$ cells isolated from mice injected with 
EL4-huCD20 tumor cells (Fig. 2). The responses induced by peptides of huMHC II_Mix 1 and of huMHC II_Mix 2 (localized in one of the intracellular domains of the CD20 molecule) were significantly higher as compared to the other mixtures (Fig. 2).

\section{MHC II-restricted CD20-derived peptides induce in vitro IF $N-\gamma$ production by $T$ cells from healthy individuals and follicular lymphoma patients}

We then investigated whether HLA-DR-restricted CD20derived peptides could stimulate the production of IFN- $\gamma$ by PBMCs from healthy donors. Since a role for T cells bearing low-avidity TCRs for self-antigens in the immune surveillance of spontaneous spleen B cell lymphoma has been reported [31], we also assessed the IFN- $\gamma$ production in response to these peptides using human spleen cells.

Three pools comprising all the peptides that activated $\mathrm{CD} 4^{+} \mathrm{T}$ cells in $\mathrm{H}-2 \mathrm{KO} / \mathrm{HLA}-\mathrm{A} 2^{+}$-DR $1^{+}$transgenic mice were designed for human ELISPOT assays (Fig. 3). The first one (termed pool 22-43) contained all the peptides of huMHC II_Mix. 1, huMHC II_Mix. 2, and huMHC II_Mix. 3. The pool 58-121 included huMHCII_Mix. 4 and huMHCII_Mix. 5 peptides, and the last one, termed 133-151, was obtained by pooling huMHC II_Mix. 6, huMHC II_Mix. 7, and huMHCII_Mix. 8 peptides (Fig. 3; Supplementary a

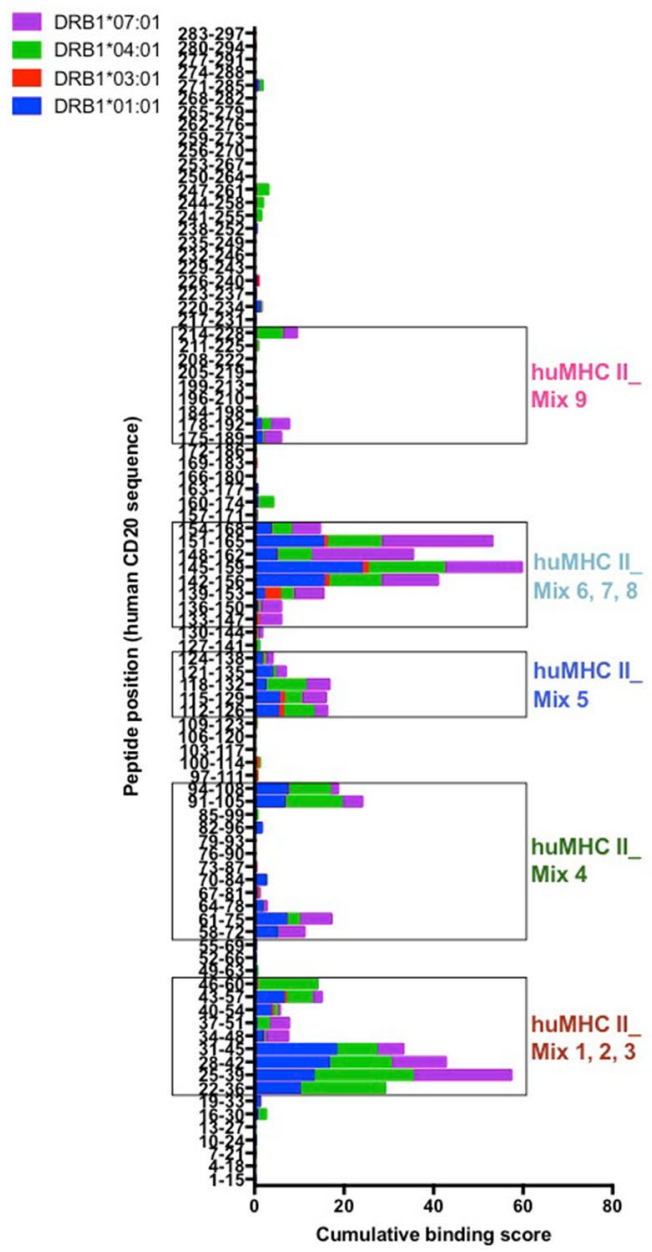

Fig. 1 Screening of immunogenic HLA-DR-restricted CD20-derived peptides. a Cumulative scores of the binding of human CD20-derived peptides to recombinant HLA-DRB1*01:01 (blue), *03:01 (red), $* 04: 01$ (green), and *07:01 (purple) molecules as calculated with the ProImmune REVEAL ${ }^{\circledR}$ MHC-peptide binding assay. High scoring peptides within intracellular, transmembrane, and extracellular domains of the human CD20 molecule were pooled into 9 different

b

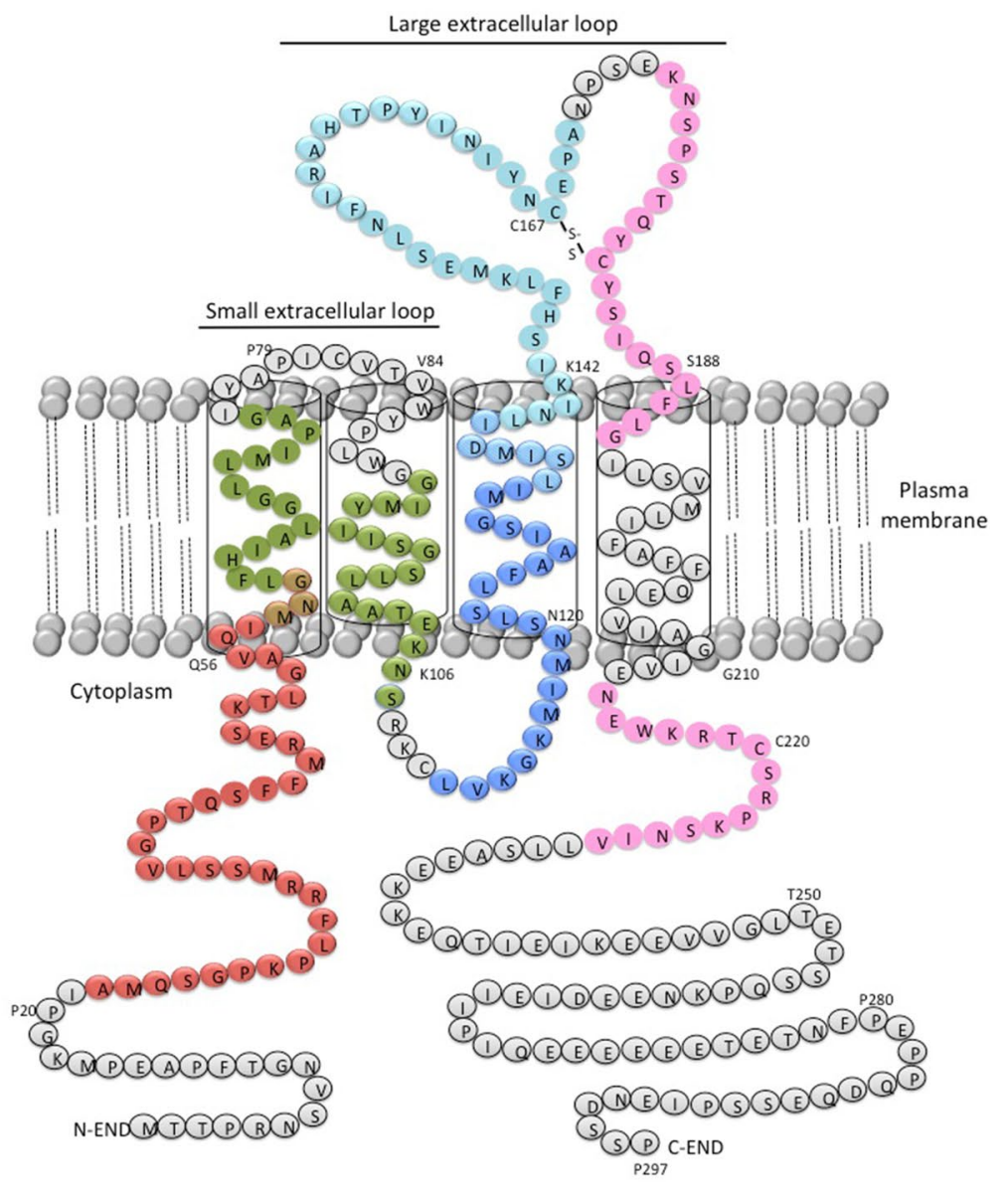

mixtures of 18 to 20-mer MHC II-restricted peptides (huMHC II_ Mix 1 to 9) (see also Supplementary Table 1). b Localization of the different MHC II-restricted CD20-derived peptide mixtures (huMHC II_Mix 1 to 3 in red; huMHC II_Mix 4 in green; huMHC II_Mix 5 in dark blue; huMHC II_Mix 6 to 8 in light blue; huMHC II_Mix 9 in pink) 


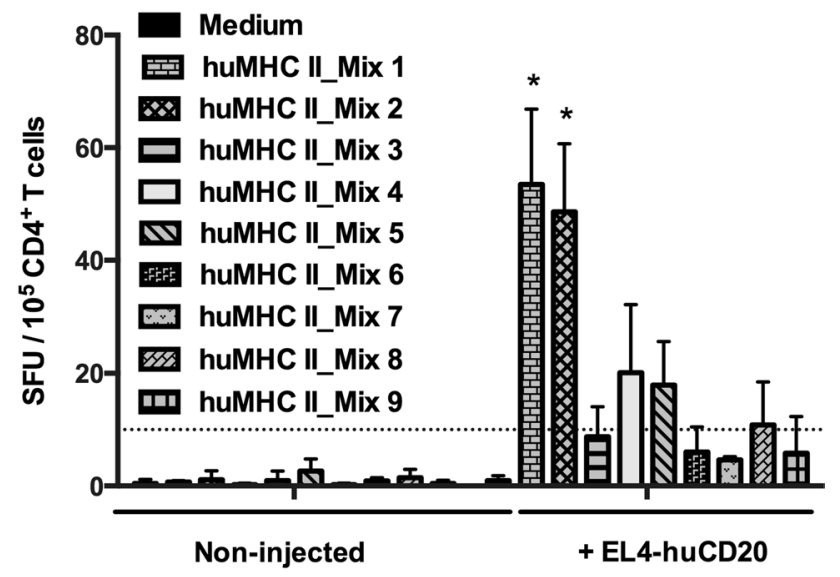

Fig. 2 Induction of $\mathrm{CD}^{+} \mathrm{T}$ cell responses directed against human CD20-derived peptides in HLA-A2.1/HLA-DR1-transgenic $\mathrm{H}-2$ class I-/class II-KO mice immunized with EL4-huCD20 tumor cells. The frequency of IFN- $\gamma$ producing $\mathrm{CD}^{+} \mathrm{T}$ cells directed against CD20-derived peptides (huMHC II_Mix 1 to huMHC II_Mix 9) from HLA-A2.1/HLA-DR1-transgenic mice inoculated with EL4huCD20 tumor cells (+EL4-huCD20) or from their naive counterparts (non-injected) was evaluated by ELISPOT assays. Results were expressed as SFU per $10^{5} \mathrm{CD}^{+} \mathrm{T}$ cells. Bars represent the mean values from two (huMHC II_Mix 3, huMHC II_Mix 5, huMHC II_Mix 6, huMHC II_Mix 7, huMHC II_Mix 8) or three (huMHC II_Mix 1, huMHC II_Mix 2, huMHC II_Mix 4, huMHC II_Mix 9) independent experiments. The positive threshold (horizontal dotted line) was set at $\geq 10$ SFU per $10^{5}$ cells as previously described [30]. *Indicates that IFN- $\gamma$ responses obtained with $\mathrm{CD} 4^{+} \mathrm{T}$ cells stimulated with huMHC II_Mix 1 or huMHC II_Mix 2 were significantly higher than those obtained in all other conditions (Multiple $t$ tests followed by Bonferroni correction)

Table 1). All three pools of MHC II-restricted CD20-derived peptides induced $\mathrm{T}$ cell responses by PBMCs or spleen cells from a number of healthy individuals (Fig. 4a, b; Supplementary Table 2). The median SFU value per $10^{5}$ cells was significantly higher for pool 133-151 (peptides located within the large extracellular loop of CD20) as compared to pool 22-43 (peptides located within the intracellular domain) (Fig. 4a, b). This was observed both with PBMCs and splenocytes. Various response profiles were observed among the HD PBMC samples. $23 \%$ exhibited IFN- $\gamma$ production in response to each of the three pools of peptides. Responses to one or two out of the three pools were detected in $19 \%$ and $15 \%$ of HD PBMC samples, respectively. IFN- $\gamma$ production in response to one or two of the three pools was detected in $28 \%$ or $57 \%$ of splenocytes, respectively (Supplementary Fig. 1). Of note, FVIII peptides used as a control for self-antigen-derived peptides (see "Materials and methods") did not induce IFN- $\gamma$ production in PBMCs from healthy donors (data not shown).

Finally, we assessed whether CD20-specific T cell responses could be detected in PBMCs from patients diagnosed with high tumor-burden FL and treated with R-CHOP (Fig. 4c). Again, the IFN- $\gamma$ ELISPOT assays revealed T cell responses against all the peptide pools (Supplementary Table 2). No significant differences in median SFU per $10^{5}$ cells were detected between the different pools of peptides (Fig. 4c), and about the same percentages of responses to one or three pools were observed (Supplementary Fig. 1). The intensity of IFN- $\gamma$ response detected in ELISPOT assays with the three pools of peptides was similar between the different types of samples (PBMCs and splenocytes from healthy individuals, and PBMCs from FL patients) (Supplementary Fig. 2).

To further analyze the involvement of $\mathrm{CD}^{+} \mathrm{T}$ cells in IFN- $\gamma$ responses detected in ELISPOT assays, a monoclonal anti-HLA-DR, -DP, -DQ blocking antibody was added to culture of PBMCs from several healthy donors and from FL patients in the presence of the different pools of CD20derived peptides (Fig. 4d-f). The IFN- $\gamma$ production could be blocked by the anti-HLA-DR, -DP, -DQ antibody for some, but not all the samples tested (Fig. 4d-f and Supplementary Fig. 3). Thus, these results indicate that $\mathrm{CD} 4^{+} \mathrm{T}$ cells are implicated in IFN- $\gamma$ response and also suggest that the presence of CD20-derived long peptides could stimulate CD8 ${ }^{+}$ $\mathrm{T}$ cells.

All the ELISPOT assays were performed after expanding cells in vitro for 7 days in presence of IL-2, IL-7, and peptide pools. Both naive $\mathrm{T}$ cell priming and memory-specific $\mathrm{T}$ cell expansion can occur in this setting. To analyze the memory $\mathrm{T}$ cell pool specifically, we performed ex vivo ELISPOT assays with the pools of peptides or with individual peptide incubated with $5 \times 10^{5}$ PBMCs for $48 \mathrm{~h}$ in absence of cytokines. A low background was observed in $6 / 10$ of the HD samples tested when cells were cultured without peptide. HD31 exhibited a marked response to pool 22-43 whereas responses to the other peptide pools were barely detected in these 6 donors (Fig. 5). Interestingly, when single peptides were tested, responses above the baseline could be observed in HD27 $\left({ }^{58} \mathrm{M}-{ }^{75} \mathrm{G} ;{ }^{142} \mathrm{~K}-{ }^{161} \mathrm{Y}\right), \mathrm{HD} 31{ }^{25} \mathrm{~S}-{ }^{44} \mathrm{~F} ;{ }^{28} \mathrm{~K}-{ }^{47} \mathrm{R}$; ${ }^{34} \mathrm{M}_{-}{ }^{53} \mathrm{G} ;{ }^{40} \mathrm{P}-{ }^{59} \mathrm{~N} ;{ }^{43} \mathrm{~S}-{ }^{60} \mathrm{G} ;{ }^{91} \mathrm{G}-{ }^{108} \mathrm{~S} ;{ }^{112} \mathrm{~L}_{-}{ }^{131} \mathrm{M} ;{ }^{115} \mathrm{G}-{ }^{134} \mathrm{~S}$; ${ }^{118} \mathrm{I}-{ }^{137} \mathrm{D} ;{ }^{121} \mathrm{~S}-{ }^{138} \mathrm{I} ;{ }^{133} \mathrm{~L}-{ }^{152} \mathrm{~L} ;{ }^{145} \mathrm{H}_{-}{ }^{164} \mathrm{I} ;{ }^{151} \mathrm{~S}-{ }^{170} \mathrm{~A}$ ), and HD33 $\left({ }^{40} \mathrm{P}-{ }^{59} \mathrm{~N} ;{ }^{148} \mathrm{~K}-{ }^{167} \mathrm{C}\right)$. Thus, memory T cells against $\mathrm{CD} 20$-derived peptides can be detected in some healthy donors using a short-term in vitro incubation.

Taken together, these results show that $\mathrm{T}$ cell responses against MHC II-restricted CD20-derived peptides are detected in samples from healthy donors and FL patients. While these $\mathrm{T}$ cells recognize epitopes located in different domains of the $\mathrm{CD} 20$ protein (extracellular, transmembrane, and intracellular domains), the intensity and frequency of $\mathrm{T}$ cell responses against epitopes in the large extracellular loop appear to be higher, at least in healthy individuals. 


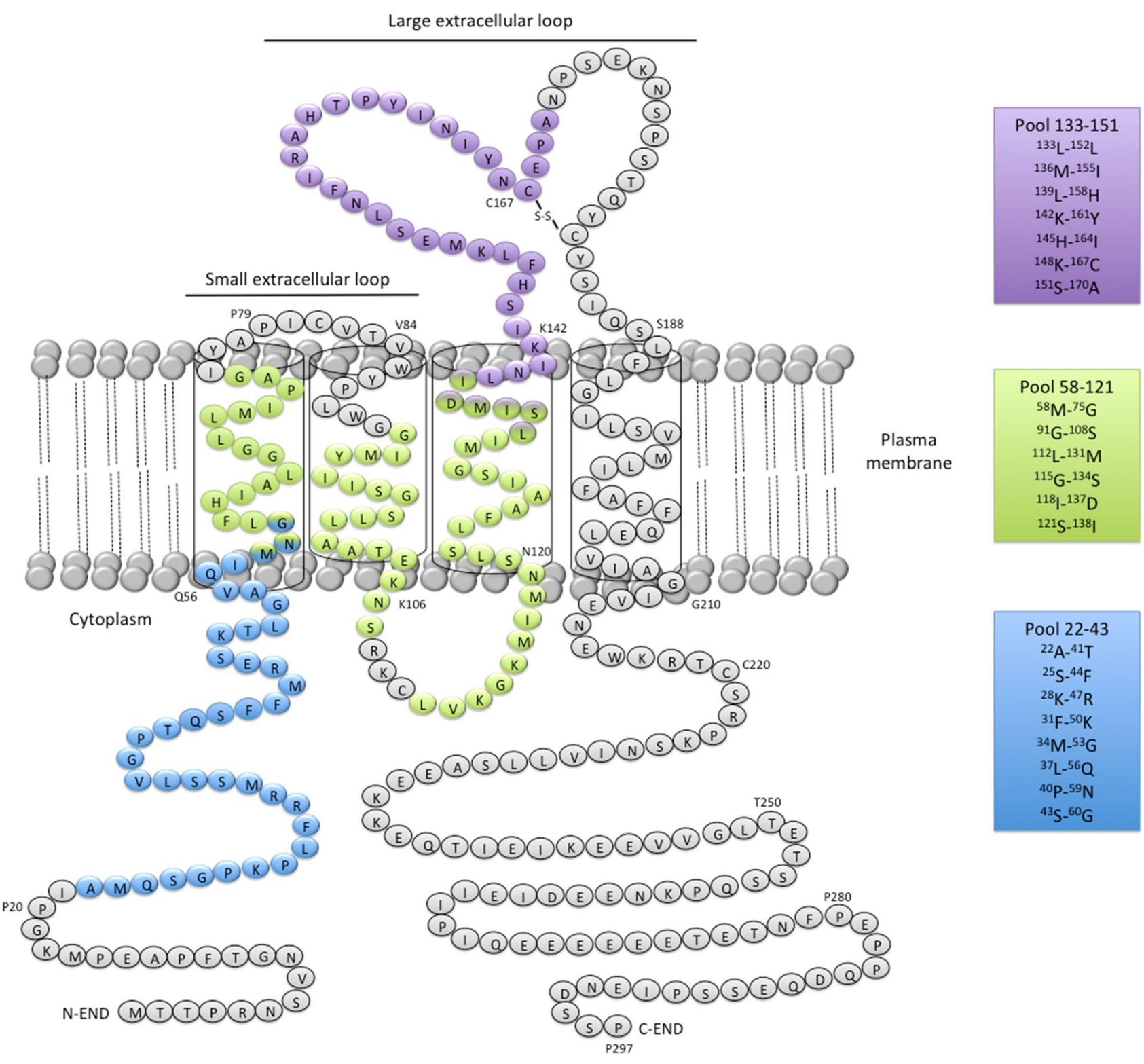

Fig. 3 Localization of HLA-DR-restricted CD20-derived peptide pools used to analyze anti-CD20 T cell responses in human PBMCs and splenocytes. Pool $22-43$ spans ${ }^{22} \mathrm{~A}-{ }^{60} \mathrm{G}$ in blue, Pool $58-121,{ }^{58} \mathrm{M}-{ }^{138} \mathrm{I}$ in green; Pool $133-151,{ }^{133} \mathrm{~L}-{ }^{170} \mathrm{~A}$ in purple

\section{Discussion}

Our previous studies performed in mice bearing EL4huCD20 tumor cells have demonstrated that a protective $\mathrm{CD} 4^{+} \mathrm{T}$ cell response directed against human $\mathrm{CD} 20$ molecule is induced after mAb treatment $[12,13]$. However, the relevant MHC II-restricted T cell epitopes are unknown. Thus, we investigated herein the presence of $\mathrm{T}$ cell epitopes in human CD20 and whether T cells directed against CD20derived peptides can be detected in human PBMCs and splenocytes.

Based on in vitro binding assays to recombinant human MHC II molecules (frequent alleles in European populations, i.e., HLA-DR1; HLA-DR3; HLA-DR4; HLADR7) and on in vivo immunization of $\mathrm{H}-2 \mathrm{KO} / \mathrm{HLA}-\mathrm{A} 2^{+}$$\mathrm{DR} 1^{+}$transgenic mice, we have identified three pools of human MHC II-restricted T cell peptides located in different domains of the $\mathrm{CD} 20$ protein that induce in vitro IFN- $\gamma$ responses in samples from healthy donors and FL patients (Fig. 4). Of note, some differences were observed between $\mathrm{H}-2 \mathrm{KO} / \mathrm{HLA}-\mathrm{A} 2^{+}$-DR $1^{+}$transgenic mice immunization and in vitro tests of human PBMCs. In experiments using $\mathrm{H}-2 \mathrm{KO} / \mathrm{HLA}-\mathrm{A} 2^{+}-\mathrm{DR} 1^{+}$transgenic mice, the responses induced by peptides localized in the $\mathrm{N}$-terminal intracellular domain of CD20 molecule (huMHC II_Mix 1 and huMHC II_Mix 2, position 22-56) were significantly 
a

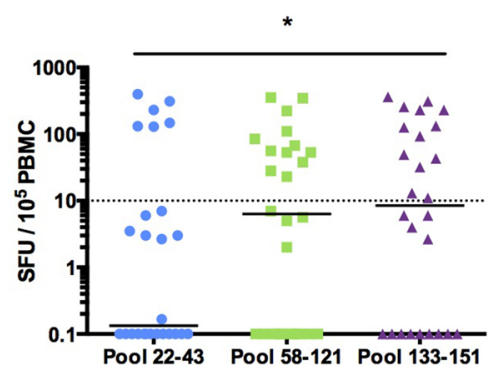

d

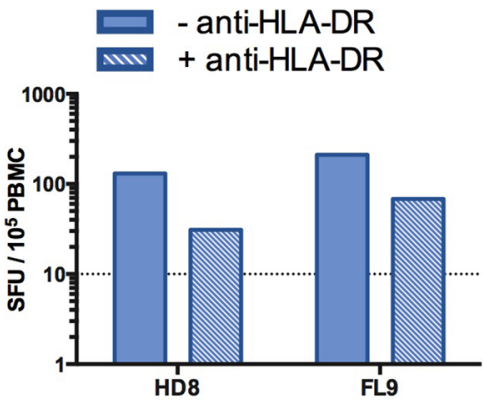

b
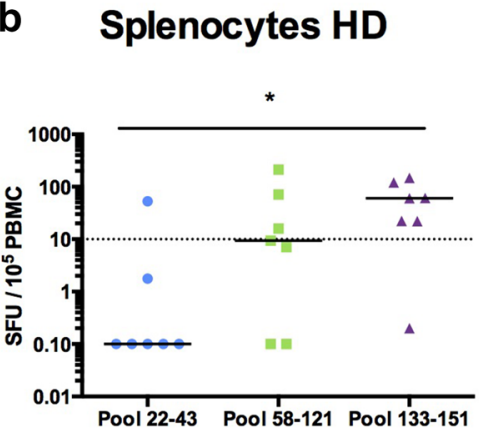

Pool 58-121

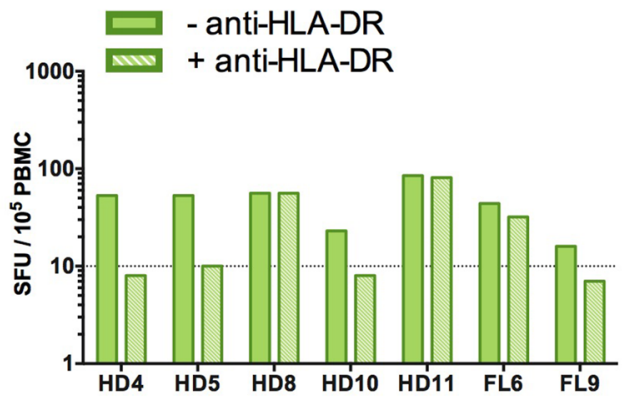

C

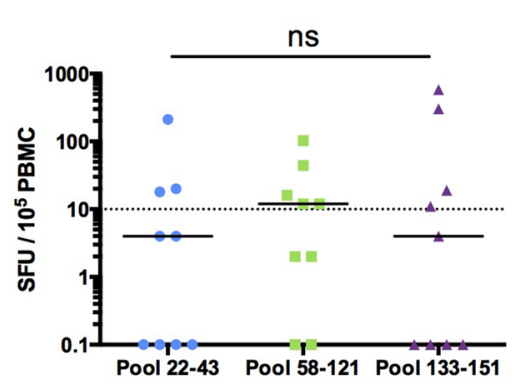

f

Pool 133-151

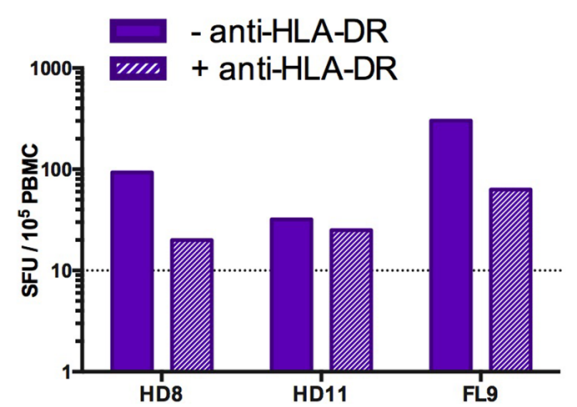

Fig. 4 IFN- $\gamma$ responses induced by HLA-DR-restricted human CD20derived peptides in healthy individuals and follicular lymphoma patients. PBMCs from a healthy donors (PBMC HD, $n=26$ ) or c follicular lymphoma patients (PBMC FL, $n=9$ ), and b splenocytes of healthy individuals (splenocytes $\mathrm{HD}, n=7$ ) were incubated with pools of MHC II-restricted CD20-derived peptides (Pools 22-43, in blue; Pool 58-121, in green; Pool 133-151, in purple). IFN- $\gamma$ production was then measured by ELISPOT assays as described in the "Materials and methods" section. Results were expressed as SFU per

higher as compared to the other peptides (Fig. 2). By contrast, when both human PBMCs and splenocytes were tested in vitro, the median SFU value per $10^{5}$ cells was significantly higher for pool 133-151 (peptides located within the large extracellular loop of CD20) as compared to the other pools (Fig. 4). These differences could be due to the fact that responses achieved in $\mathrm{H}-2 \mathrm{KO} / \mathrm{HLA}-\mathrm{A} 2^{+}$$\mathrm{DR} 1^{+}$transgenic mice result from the presentation of CD20-derived peptides solely by an HLA-DR1 molecule. By contrast, the PBMCs used in ELISPOT assays are derived from individuals with HLA-DR1 and/or HLADR3, HLA-DR4, HLA-DR7 haplotypes. The use of H-2 $\mathrm{KO} / \mathrm{HLA}-\mathrm{A} 2^{+}-\mathrm{DR} 1^{+}$transgenic mice inoculated with EL4-huCD20 tumor cells enables the detection of mouse T cell responses directed against human CD20, a xenogeneic antigen in this setting, in contrast to the assays with human samples in which autologous CD20-derived peptides are used. Nevertheless, this preclinical model represents a valuable tool to establish that peptides selected in silico can be presented in vivo by human HLA-DR1.
$10^{5}$ cells. Median values are indicated for each pool of peptides. The positive threshold (horizontal dotted line) was set at $\geq 10$ SFU per $10^{5}$ cells as previously described [30]. Non-parametric paired Wilcoxon tests were used for statistical analysis. ${ }^{*} p<0.05$; $n s$ not significant. d-f IFN- $\gamma$ production by PBMCs from healthy donors (HD4, HD5, HD8, HD10, HD11) or from FL patients (FL6 and FL9) measured by ELISPOT assays in response to d Pool 22-43, e Pool 58-121 or f Pool 133-151, in absence (- anti-HLA-DR) or presence (+antiHLA-DR) of blocking anti-HLA-DR, -DP, -DQ monoclonal antibody

Our results also indicate that peptides derived from the huCD20 sequence ${ }^{133} \mathrm{~L}-{ }^{170} \mathrm{~A}$ (located in the large extracellular loop) are the most immunogenic. This observation is reminiscent of a previous study showing the induction of an antibody response in BALB/c mice vaccinated with a peptide from the human CD20 extracellular loop sequence (CKISHFLKMESLNFIRAHTPYINIYNCEPANPSEKNS PSTQYCY) [32]. However, although the intensity and frequency of $\mathrm{T}$ cell responses against epitopes localized in the large extracellular loop appear to be higher, at least in healthy donors, IFN- $\gamma$ responses to peptides derived from the intracellular and transmembrane domains (Pools 22-43 and 58-121) were also detected in some individuals. Thus, in addition to MHC I-restricted peptides derived from the extracellular CD20 loop previously described [16-22], we were able herein to define 15 to 20-mer MHC II-restricted $\mathrm{T}$ cell epitopes derived from either intracellular, membrane, or extracellular domains of the human non-mutated CD20 protein. Of note, the data obtained in the presence of antiHLA-DR, -DP, -DQ blocking antibody suggest that these 


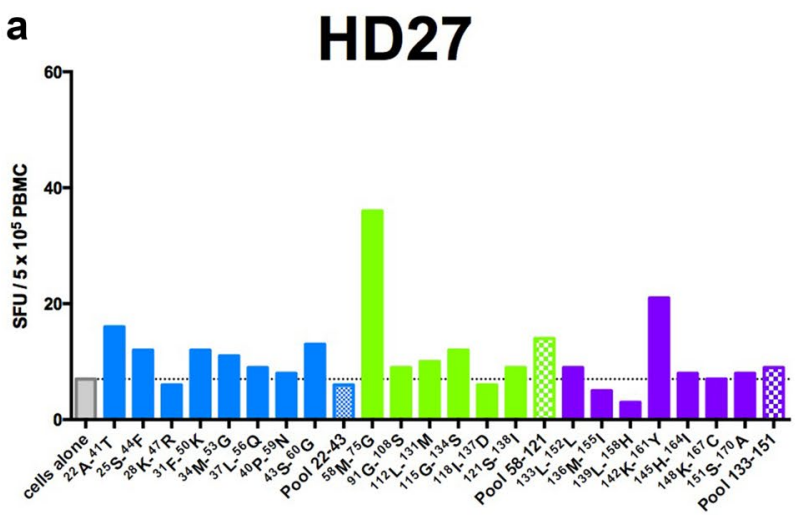

C
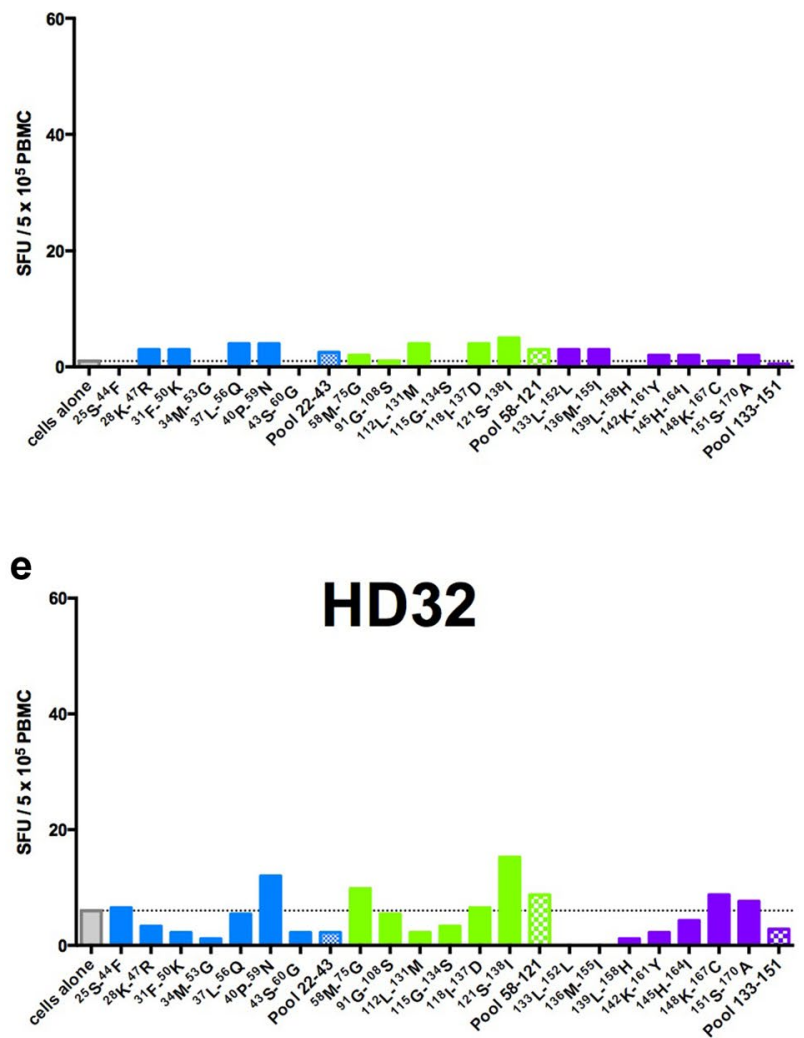

Fig. 5 IFN- $\gamma$ responses to individual peptides by PBMCs from healthy donors HD27 (a), HD28 (b), HD30 (c), HD31 (d), HD32 (e), HD33 (f). Horizontal dotted line and gray bar represent the number of SFU $/ 5 \times 10^{5}$ PBMCs obtained when cells are cultured alone (background). Bars represent results from individual peptides from pool

long peptides also have the ability to stimulate $\mathrm{CD} 8^{+} \mathrm{T}$ cells in vitro for some individuals as already reported in other studies [reviewed in 33].

We cannot exclude that the immunogenic peptides for which a $\mathrm{CD}^{+} \mathrm{T}$ cell response is detected in individuals included in our study are different to the endogenously expressed CD20 polypeptide. Low-frequency mutations

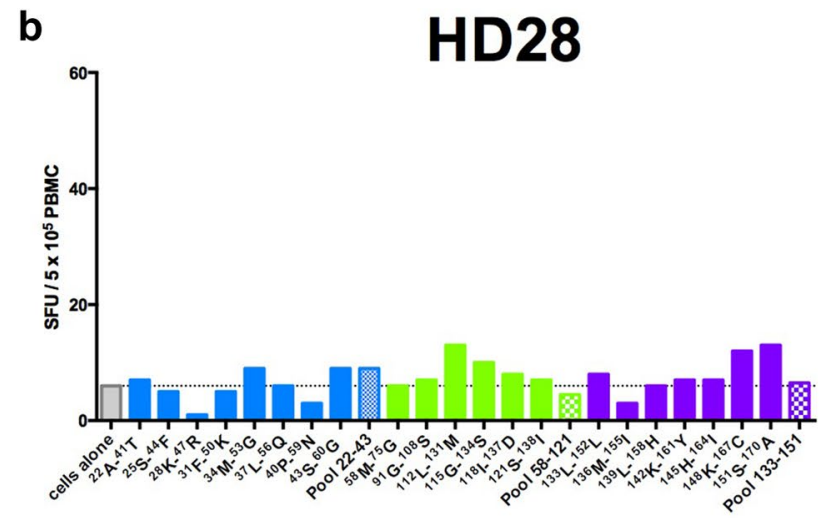

d

HD31

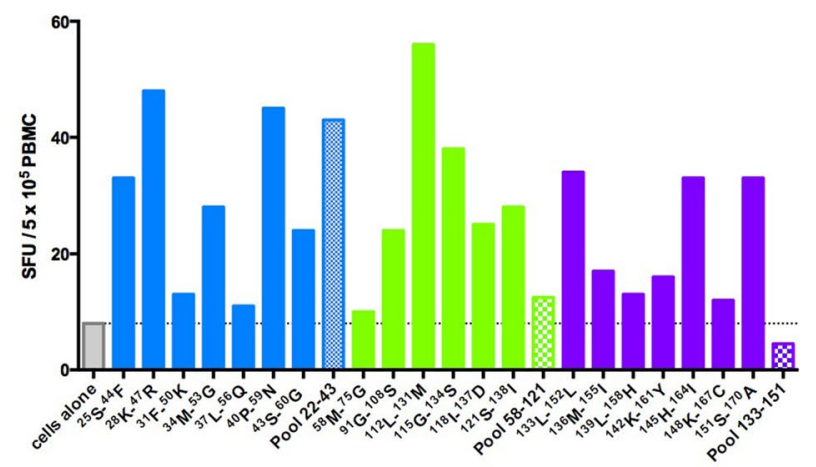

f

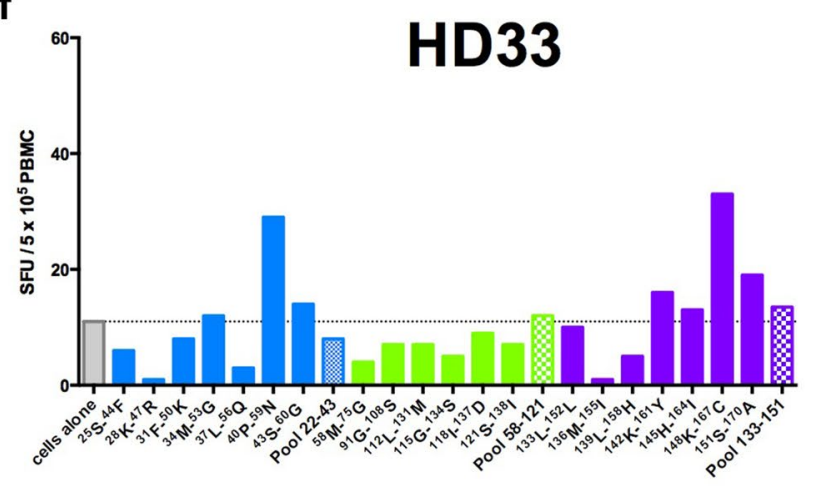

22-43 (blue), pool 58-121 (green), and pool 133-151 (purple) (one well/peptide). Hatched bars represent results with the three pools: pool 22-43, blue; pool 58-121, green; pool 133-151, purple (1 well/ pool)

including SNPs or polymorphisms of the CD20-encoding MS4A1 gene have been observed in NHL patients [34-37]. It has been suggested that some CD20 tumor-associated mutations could be treatment induced [37]. Five CD20 alternative splice variants have also been identified in human Epstein-Barr Virus (EBV)-transformed B cell lines and in primary samples of FL, CLL, mantle cell lymphoma 
(MCL) or diffuse large B cell lymphoma (DLBCL) patients [38-40]. Interestingly, specific $\mathrm{T}$ cell responses against a 20-mer peptide derived from one of these CD20 splice variants (D393-CD20) were detected in both lymphoma patients and healthy individuals [39]. However, it is important to stress that no splice variants were observed in normal B cells from healthy donors in these studies and that the different splice variants and the wild-type CD20 isoform are coexpressed in NHL B cell patients [39, 40]. It is thus unlikely that an allogeneic $\mathrm{T}$ cell response is being observed rather than an autoreactive $\mathrm{T}$ cell response in our experimental setting.

Non-mutated self-proteins overexpressed on tumor cells are a source of universal target antigens for inducing tumor-specific $\mathrm{T}$ lymphocytes without the need to identify the mutanome of tumor cells. Recent results have demonstrated that thymic deletion prunes but does not eliminate self-specific $\mathrm{CD}^{+}{ }^{+}$and $\mathrm{CD} 8^{+} \mathrm{T}$ cells, and that some selfpeptide/MHC-restricted $\mathrm{T}$ cells can be detected at frequencies similar to those of $\mathrm{T}$ cells specific for non-self-antigens [41-44]. While the use of such epitopes could be limited by self-tolerant $\mathrm{T}$ cell repertoire, therapeutic strategies have been developed to overcome the tolerance of $\mathrm{T}$ cells to selfpeptides. For example, adjuvants, lentivectors, or inhibitory immune checkpoint blocking molecules can improve the efficacy of self-peptide-based vaccinations [45, 46]. Moreover, anti-CA125, anti-HER2/neu, anti-MUC1, anti-EGFR mAb treatment can circumvent the tolerance to self-antigens expressed on tumor cells as shown by the increase of the frequency of $\mathrm{CD}^{+}$and/or $\mathrm{CD} 8^{+} \mathrm{T}$ cells recognizing peptides derived from the target molecule in cancer patients [47-51].

In our experimental setting, priming of naive $\mathrm{T}$ cells in addition to the activation of memory $T$ cells can likely occur during the 7-day expansion. Different studies have shown that $\mathrm{T}$ cells specific to a given antigen can be detected in the naive but not in the memory $\mathrm{T}$ cell compartment in non-immune donors $[52,53]$. This is consistent with the high diversity of the naive repertoire as compared to the much lower diversity of the memory repertoire, which represents a collection of clones selected during immune responses. In these studies, an amplification step has been used to detect these specific $\mathrm{T}$ cells due to their very low frequencies in the naive repertoire. These observations underline the importance of exploring both the naive and memory repertoires to identify anti-CD20specific $\mathrm{CD}^{+}{ }^{+} \mathrm{T}$ cells that can be manipulated in the context of vaccination strategies. Our data suggest that both naive and memory anti-CD20 T cells can be present in healthy donors.

In conclusion, our results indicate that carefully selected CD20-derived MHC II-restricted peptides make it possible to induce $\mathrm{CD} 20$-specific $\mathrm{CD} 4^{+} \mathrm{T}$ cell responses in humanized HLA-DR-transgenic mice and in human PBMCs. These peptides could serve as a therapeutic tool in B cell malignancies to improve the antitumor activity of $\mathrm{CD}^{+}{ }^{+} \mathrm{T}$ cells in the context of vaccination strategies by helping $\mathrm{CD} 8^{+} \mathrm{T}$ cell response and eventually through direct cytotoxic effector functions [54]. Furthermore, our results indicate that antiCD20 T cells present in FL patients exhibit various epitope specificities (Fig. 2; Supplementary Table 2). This finding suggests that any vaccination approach based on the use of CD20-derived peptide pools should include pre-screening of patients who respond to these pools. CD20-derived peptides could also be used ex vivo to develop an adoptive T cell immunotherapy strategy. Finally, they could help in monitoring the anti-tumor $\mathrm{T}$ cell responses in patients treated with rituximab or other anti-CD20 antibodies.

Acknowledgements The authors thank Patricia Rezgui (Hematooncology Department, Saint Louis hospital, Paris, France) for blood sample collection and all the patients who contributed to this study. Factor VIII-derived peptides were kindly provided by Sandrine Delignat and Sébastien Lacroix-Desmazes (Cordeliers Research Center, Paris, France). English writing assistance was provided by Jo Ann Cahn, Donald Zack (Johns Hopkins University School of Medicine, Baltimore, MD, USA), and Aditi Varthaman (Cordeliers Research Center, Paris, France).

Author contributions BM, PB, CT, J-LT, and SS designed the study. BM, J-LT, and SS conceived and wrote the manuscript. SA, PB, and CT provided samples from FL patients. RJ-M and SG-D provided splenocytes from healthy individuals. BM, NJ, QR, IG, ER, CD, SS, and J-LT performed and analyzed the experiments. PL and AT performed HLA typing. SG-D, PL, and AT provided assistance for the design of CD20-derived peptides. J-BL, MH, AC, and OT have developed and provided NIH-3T3 cell line-derived artificial antigen-presenting cells expressing HLA-DRB1*0:01. Y-CL developed HLA-A2.1-/HLA-DR1transgenic $\mathrm{H}-2$ class I-/class II-KO mice and gave helpful advice for the design of experiments using these mice. All authors critically reviewed the manuscript and approved the final version.

Funding Benoit Milcent was supported by a fellowship from the Cancer Research for Personalized Medicine (CARPEM) association. Sophie Sibéril was supported by a grant from Fondation Association pour la Recherche sur le Cancer (ARC) (Grant number, ARC PJA20131200475) and Jean-Luc Teillaud and Sophie Sibéril by funding from the Institut national de la Santé et de la Recherche Médicale (INSERM), Sorbonne University and Paris-Descartes University. Catherine Thieblemont is funded by the Nella and Amadeus Barletta foundation (FNAB).

\section{Compliance with ethical standards}

Conflict of interest The authors declare no conflict of interest.

Ethical approval and ethical standards This non-interventional study, which complies with the Declaration of Helsinki, was approved by the appropriate regional ethics committee ("Comités de Protection des Personnes", Ile-de-France, France) regulated by the government institution "Agence Régionale de Santé" (ARS, Bobigny, France), by the government advisory board for data processing in health care ("Comité Consultatif sur le Traitement de l'Information en matière de Recherche dans le Domaine de la Santé", Paris, France) (CCTIRS N $\left.{ }^{\circ} 14.626\right)$, and by the French data protection authority ("Commission Nationale de 
l'Informatique et des Libertés », Paris, France) (CNIL NDR-2015237). PBMCs from HD were obtained from CTL-Europe or from the EFS. Spleens were obtained from organ transplant donors at the Hôpital Pitié-Salpêtrière (Paris, France), in accordance with national ethics guidelines governing the use of human tissues (Scientific collecting authorization, government institution "Agence de la biomédecine", Saint Denis, France) (NPFS14-009). All animal studies were performed in compliance with guidelines from the European Union (EU guideline on animal experiments, European Directive \#2010/63/ EU) and the national charter on ethics in animal experiments and were approved by the local Charles Darwin Ethics Committee in Animal Experiments, Paris, France (Authorization Number 01530.02).

Informed consent All FL patients provided informed written consent to participate in this research study (CCTIRS $\mathrm{N}^{\circ} 14.626$ and CNIL $\mathrm{N}^{\circ}$ DR-2015-237). Written informed consents were obtained by the French state agency EFS (www.efs.sante.fr) for the use of blood of anonymous healthy donors for research purposes. Human PBMCs from CTL-Europe were collected from sources that have confirmed that they were obtained from healthy donors with informed consent in accordance with applicable laws. Spleens were collected from organ transplant donors at the Hôpital Pitié-Salpétrière (Paris, France) (written protocol $\mathrm{N}^{\circ}$ PFS14-009, Agence de la biomédecine), following national ethical guidelines (L1232-1, L1232-3; www.legifrance.gouv.fr) regulating the use of human tissues for research purposes.

Animal source HLA-A2.1-/HLA-DR1-transgenic H-2 class I-/class II-KO female C57B1/6 mice were developed by Dr. Lone at Institut Pasteur-Paris in Dr. F. Lemonnier laboratory. HLA-A2.1 transgenic $\mathrm{H}-2$ class I-KO $\left(\beta 2 \mathrm{~m}^{0}\right)$ (obtained at Institut Pasteur-Paris in Dr. F. Lemonnier laboratory) and HLA-DR1 transgenic H-2 class II-KO (IA $\beta^{\mathrm{b}^{\circ}}$ ) (obtained at Institut Pasteur-Lille from Dr. C. Auriault) mice were intercrossed and progenies screened until HLA-A2.1 ${ }^{+/+} / \mathrm{HLA}-\mathrm{DR} 1^{+/+}$ double-transgenic H-2 class I-/class II-KO animals were obtained [24]. All mice were maintained in pathogen-free facilities.

Cell line authentification C57BL/6 mice-derived EL4 thymoma cells expressing human CD20 (EL4-huCD20) were kindly provided by Pr. Josée Golay from the Center of Cellular Therapy "G. Lanzani", USC Haematology, Azienda Socio Sanitaria Territoriale Papa Giovanni XXIII, Bergamo, Italy. EL4 cells obtained from the AmericanType Culture Collection (ATCC, Manassas, VA) were infected with the Moloney-derived long terminal repeat (LTR)-CD20-LTR vector containing the human CD20 cDNA [25]. The expression of human CD20 on EL4-huCD20 cells was validated before each experiment by flow cytometry using a mouse anti-human CD20 mAb (2H7, BD Biosciences). HLA-DRB $1 * 01$ :01-expressing AAPCs derived from murine fibroblasts NIH-3T3 cells were developed by Dr. Toutirais and Dr. Latouche. NIH-3T3 cells (obtained from ATCC) were transduced with the common HLA-DR $\alpha$ chain, the specific HLA-DR $\beta 1 * 01: 01$ chain, and with the co-stimulatory and adhesion human molecules B7.1, ICAM-1 and LFA-3 [26]. Phenotypic expression of transduced molecules on AAPCs was validated by flow cytometry using anti-human LFA-3, B7.1, ICAM-1 mAbs (BD Biosciences) and an anti-HLA-DR complex mAb (Santa Cruz Biotechnology).

Open Access This article is distributed under the terms of the Creative Commons Attribution 4.0 International License (http://creativeco mmons.org/licenses/by/4.0/), which permits unrestricted use, distribution, and reproduction in any medium, provided you give appropriate credit to the original author(s) and the source, provide a link to the Creative Commons license, and indicate if changes were made.

\section{References}

1. Marshall MJE, Stopforth RJ, Cragg MS (2017) Therapeutic antibodies: what have we learnt from targeting CD20 and where are we going? Front Immunol 8:1245

2. Beers SA, Chan CH, French RR, Cragg MS, Glennie MJ (2010) CD20 as a target for therapeutic type I and II monoclonal antibodies. Semin Hematol 47:107-114

3. Stashenko P, Nadler LM, Hardy R, Schlossman SF (1980) Characterization of a human B lymphocyte-specific antigen. J Immunol 125:1678-1685

4. Stashenko P, Nadler LM, Hardy R, Schlossman SF (1981) Expression of cell surface markers after human B lymphocyte activation. Proc Natl Acad Sci USA 78:3848-3852

5. Nadler LM, Stashenko P, Hardy R, van Agthoven A, Terhorst C, Schlossman SF (1981) Characterization of a human B cell-specific antigen (B2) distinct from B1. J Immunol 126:1941-1947

6. Tedder TF, Engel P (1994) CD20: a regulator of cell-cycle progression of B lymphocytes. Immunol Today 15:450-454

7. Deans JP, Schieven GL, Shu GL, Valentine MA, Gilliland LA, Aruffo A, Clark EA, Ledbetter JA (1993) Association of tyrosine and serine kinases with the $\mathrm{B}$ cell surface antigen $\mathrm{CD} 20$. Induction via CD20 of tyrosine phosphorylation and activation of phospholipase C-gamma 1 and PLC phospholipase C-gamma 2. J Immunol 151:4494-4504

8. Deans JP, Robbins SM, Polyak MJ, Savage JA (1998) Rapid redistribution of CD20 to a low-density detergent-insoluble membrane compartment. J Biol Chem 273:344-348

9. Bubien JK, Zhou LJ, Bell PD, Frizzell RA, Tedder TF (1993) Transfection of the CD20 cell surface molecule into ectopic cell types generates a $\mathrm{Ca} 2+$ conductance found constitutively in $\mathrm{B}$ lymphocytes. J Cell Biol 121:1121-1132

10. Klein C, Lammens A, Schäfer W, Georges G, Schwaiger M, Mössner E, Hopfner KP, Umaña P, Niederfellner G (2013) Epitope interactions of monoclonal antibodies targeting CD20 and their relationship to functional properties. MAbs 5:22-33

11. Teeling JL, Mackus WJ, Wiegman LJ, van den Brakel JH, Beers SA, French RR, van Meerten T, Ebeling S, Vink T, Slootstra JW, Parren PW, Glennie MJ, van de Winkel JG (2006) The biological activity of human CD20 monoclonal antibodies is linked to unique epitopes on CD20. J Immunol 177:362-371

12. Abès R, Gélizé E, Fridman WH, Teillaud JL (2010) Long-lasting antitumor protection by anti-CD20 antibody through cellular immune response. Blood 116:926-934

13. Deligne C, Metidji A, Fridman WH, Teillaud JL (2015) AntiCD20 therapy induces a memory Th1 response through the IFN- $\gamma /$ IL-12 axis and prevents protumor regulatory T-cell expansion in mice. Leukemia 29:947-957

14. DiLillo DJ, Ravetch JV (2015) Differential Fc-receptor engagement drives an anti-tumor vaccinal effect. Cell 161:1035-1045

15. Hassan C, Kester MG, de Ru AH, Hombrink P, Drijfhout JW, Nijveen H, Leunissen JA, Heemskerk MH, Falkenburg JH, van Veelen PA (2013) The human leukocyte antigen-presented ligandome of B lymphocytes. Mol Cell Proteomics 12:1829-1843

16. Kowalewski DJ, Schuster H, Backert L, Berlin C, Kahn S, Kanz L, Salih HR, Rammensee HG, Stevanovic S, Stickel JS (2015) HLA ligandome analysis identifies the underlying specificities of spontaneous antileukemia immune responses in chronic lymphocytic leukemia (CLL). Proc Natl Acad Sci USA 112:E166-E175

17. Grube M, Rezvani K, Wiestner A, Fujiwara H, Sconocchia G, Melenhorst JJ, Hensel N, Marti GE, Kwak LW, Wilson W, Barrett JA (2004) Autoreactive, cytotoxic T lymphocytes specific for peptides derived from normal B-cell differentiation antigens in healthy individuals and patients with B-cell malignancies. Clin Cancer Res 10:1047-1056 
18. Bae J, Martinson JA, Klingemann HG (2005) Identification of CD19 and CD20 peptides for induction of antigen-specific CTLs against B-cell malignancies. Clin Cancer Res 11:1629-1638

19. Abrahamsen IW, Kjellevoll S, Greve-Isdahl M, Mensali N, Wälchli S, Kumari S, Loland BF, Egeland T, Kolstad A, Olweus J (2012) T cells raised against allogeneic HLA-A2/CD20 kill primary follicular lymphoma and acute lymphoblastic leukemia cells. Int J Cancer 130:1821-1832

20. Mensali N, Ying F, Sheng VO, Yang W, Walseng E, Kumari S, Fallang LE, Kolstad A, Uckert W, Malmberg KJ, Wälchli S, Olweus J (2016) Targeting B-cell neoplasia with T-cell receptors recognizing a CD20-derived peptide on patient-specific HLA. Oncoimmunology 18(5):e1138199

21. Jahn L, van der Steen DM, Hagedoorn RS, Hombrink P, Kester MG, Schoonakker MP, de Ridder D, van Veelen PA, Falkenburg JH, Heemskerk MH (2016) Generation of CD20-specific TCRs for TCR gene therapy of CD20low B-cell malignancies insusceptible to CD20-targeting antibodies. Oncotarget 7:77021-77037

22. Kumari S, Wälchli S, Fallang LE, Yang W, Lund-Johansen F, Schumacher TN, Olweus J (2014) Alloreactive cytotoxic T cells provide means to decipher the immunopeptidome and reveal a plethora of tumor-associated self-epitopes. Proc Natl Acad Sci USA 111:403-408

23. Vauchy C, Gamonet C, Ferrand C, Daguindau E, Galaine J, Beziaud L, Chauchet A, Henry Dunand CJ, Deschamps M, Rohrlich PS, Borg C, Adotevi O, Godet Y (2015) CD20 alternative splicing isoform generates immunogenic CD4 helper T epitopes. Int $\mathrm{J}$ Cancer 137:116-126

24. Pajot A, Michel ML, Fazilleau N, Pancré V, Auriault C, Ojcius DM, Lemonnier FA, Lone YC (2004) A mouse model of human adaptive immune functions: HLA-A2.1-/HLA-DR1-transgenic H-2 class I-/class II-knockout mice. Eur J Immunol 34:3060-3069

25. Di Gaetano N, Cittera E, Nota R, Vecchi A, Grieco V, Scanziani E, Botto M, Introna M, Golay J (2003) Complement activation determines the therapeutic activity of rituximab in vivo. J Immunol 171:1581-1587

26. Garnier A, Hamieh M, Drouet A, Leprince J, Vivien D, Frébourg T, Le Mauff B, Latouche JB, Toutirais O (2016) Artificial antigenpresenting cells expressing HLA class II molecules as an effective tool for amplifying human specific memory CD4(+) T cells. Immunol Cell Biol 94:662-672

27. Steinitz KN, van Helden PM, Binder B, Wraith DC, Unterthurner S, Hermann C, Schuster M, Ahmad RU, Weiller M, Lubich C, de la Rosa M, Schwarz HP, Reipert BM (2012) CD4 + T-cell epitopes associated with antibody responses after intravenously and subcutaneously applied human FVIII in humanized hemophilic E17 HLA-DRB1*1501 mice. Blood 119:4073-4082

28. Jones TD, Phillips WJ, Smith BJ, Bamford CA, Nayee PD, Baglin TP, Gaston JS, Baker MP (2005) Identification and removal of a promiscuous $\mathrm{CD} 4+\mathrm{T}$ cell epitope from the $\mathrm{C} 1$ domain of factor VIII. J Thromb Haemost 3:991-1000

29. van Haren SD, Herczenik E, ten Brinke A, Mertens K, Voorberg J, Meijer AB (2011) HLA-DR-presented peptide repertoires derived from human monocyte-derived dendritic cells pulsed with blood coagulation factor VIII. Mol Cell Proteomics 10(M110):002246

30. Godet Y, Fabre E, Dosset M, Lamuraglia M, Levionnois E, Ravel P, Benhamouda N, Cazes A, Le Pimpec-Barthes F, Gaugler B, Langlade-Demoyen P, Pivot X, Saas P, Maillère B, Tartour E, Borg C, Adotévi O (2012) Analysis of spontaneous tumor-specific CD4 T-cell immunity in lung cancer using promiscuous HLADR telomerase-derived epitopes: potential synergistic effect with chemotherapy response. Clin Cancer Res 18:2943-2953

31. Afshar-Sterle S, Zotos D, Bernard NJ, Scherger AK, Rödling L, Alsop AE, Walker J, Masson F, Belz GT, Corcoran LM, O'Reilly LA, Strasser A, Smyth MJ, Johnstone R, Tarlinton DM, Nutt SL, Kallies A (2014) Fas ligand-mediated immune surveillance by $T$ cells is essential for the control of spontaneous B cell lymphomas. Nat Med 20:283-290

32. Roberts WK, Livingston PO, Agus DB, Pinilla-Ibarz J, Zelenetz A, Scheinberg DA (2002) Vaccination with CD20 peptides induces a biologically active, specific immune response in mice. Blood 99:3748-3755

33. Melief CJ, van der Burg SH (2008) Immunotherapy of established (pre)malignant disease by synthetic long peptide vaccines. Nat Rev Cancer 8:351-360

34. Ding H, Jin X, Ding N, Fu Z, Song Y, Zhu J (2013) Single nucleotide polymorphisms of $\mathrm{CD} 20$ gene and their relationship with clinical efficacy of R-CHOP in patients with diffuse large B cell lymphoma. Cancer Cell Int 13:58

35. Sar A, Perizzolo M, Stewart D, Mansoor A, Difrancesco LM, Demetrick DJ (2009) Mutation or polymorphism of the CD20 gene is not associated with the response to R-CHOP in diffuse large B cell lymphoma patients. Leuk Res 33:792-797

36. Johnson NA, Leach S, Woolcock B, deLeeuw RJ, Bashashati A, Sehn LH, Connors JM, Chhanabhai M, Brooks-Wilson A, Gascoyne RD (2009) CD20 mutations involving the rituximab epitope are rare in diffuse large B-cell lymphomas and are not a significant cause of R-CHOP failure. Haematologica 94:423-427

37. Terui Y, Mishima Y, Sugimura N, Kojima K, Sakurai T, Mishima Y, Kuniyoshi R, Taniyama A, Yokoyama M, Sakajiri S, Takeuchi K, Watanabe C, Takahashi S, Ito Y, Hatake K (2009) Identification of CD20 C-terminal deletion mutations associated with loss of CD20 expression in non-Hodgkin's lymphoma. Clin Cancer Res 15:2523-2530

38. Henry C, Deschamps M, Rohrlich PS, Pallandre JR, Rémy-Martin JP, Callanan M, Traverse-Glehen A, GrandClément C, GarnacheOttou F, Gressin R, Deconinck E, Salles G, Robinet E, Tiberghien P, Borg C, Ferrand C (2010) Identification of an alternative CD20 transcript variant in B-cell malignancies coding for a novel protein associated to rituximab resistance. Blood 115:2420-2429

39. Vauchy C, Gamonet C, Ferrand C, Daguindau E, Galaine J, Beziaud L, Chauchet A, Henry Dunand CJ, Deschamps M, Rohrlich PS, Borg C, Adotevi O, Godet Y (2015) CD20 alternative splicing isoform generates immunogenic $\mathrm{CD} 4$ helper $\mathrm{T}$ epitopes. Int $\mathrm{J}$ Cancer 137:116-126

40. Gamonet C, Bole-Richard E, Delherme A, Aubin F, Toussirot E, Garnache-Ottou F, Godet Y, Ysebaert L, Tournilhac O, Caroline D, Larosa F, Deconinck E, Saas P, Borg C, Deschamps M, Ferrand C (2016) New CD20 alternative splice variants: molecular identification and differential expression within hematological B cell malignancies. Exp Hematol Oncol 5:7

41. Velthuis JH, Unger WW, Abreu JR, Duinkerken G, Franken K, Peakman M, Bakker AH, Reker-Hadrup S, Keymeulen B, Drijfhout JW, Schumacher TN, Roep BO (2010) Simultaneous detection of circulating autoreactive CD8 + T-cells specific for different islet cell-associated epitopes using combinatorial MHC multimers. Diabetes 59:1721-1730

42. Delluc S, Ravot G, Maillere B (2010) Quantification of the preexisting CD4 T-cell repertoire specific for human erythropoietin reveals its immunogenicity potential. Blood 116:4542-4545

43. Yu W, Jiang N, Ebert PJ, Kidd BA, Müller S, Lund PJ, Juang J, Adachi K, Tse T, Birnbaum ME, Newell EW, Wilson DM, Grotenbreg GM, Valitutti S, Quake SR, Davis MM (2015) Clonal deletion prunes but does not eliminate self-specific $\alpha \beta$ CD8(+) T lymphocytes. Immunity 42:929-941

44. Chevaleyre C, Benhamouda N, Favry E, Fabre E, Mhoumadi A, Nozach H, Marcon E, Cosler G, Vinatier E, Oudard S, Hans S, Le Pimpec-Barthes F, Bats AS, Castelli FA, Tartour E, Maillère B (2015) The tumor antigen cyclin B1 hosts multiple CD4 T cell epitopes differently recognized by pre-existing naive and memory cells in both healthy and cancer donors. J Immunol 195:1891-1901 
45. Liu Y, Peng Y, Mi M, Guevara-Patino J, Munn DH, Fu N, He Y (2009) Lentivector immunization stimulates potent CD8 T cell responses against melanoma self-antigen tyrosinase-related protein 1 and generates antitumor immunity in mice. J Immunol 182:5960-5969

46. Sierro SR, Donda A, Perret R, Guillaume P, Yagita H, Levy F, Romero P (2011) Combination of lentivector immunization and low-dose chemotherapy or PD-1/PD-L1 blocking primes selfreactive $\mathrm{T}$ cells and induces anti-tumor immunity. Eur J Immunol 41:2217-2228

47. Noujaim AA, Schultes BC, Baum RP, Madiyalakan R (2001) Induction of CA125-specific B and T cell responses in patients injected with MAb-B43.13-evidence for antibody-mediated antigen-processing and presentation of CA125 in vivo. Cancer Biother Radiopharm 16:187-203

48. de Bono JS, Rha SY, Stephenson J, Schultes BC, Monroe P, Eckhardt GS, Hammond LA, Whiteside TL, Nicodemus CF, Cermak JM, Rowinsky EK, Tolcher AW (2004) Phase I trial of a murine antibody to MUC1 in patients with metastatic cancer: evidence for the activation of humoral and cellular antitumor immunity. Ann Oncol 15:1825-1833

49. Taylor C, Hershman D, Shah N, Suciu-Foca N, Petrylak DP, Taub R, Vahdat L, Cheng B, Pegram M, Knutson KL, Clynes R (2007) Augmented HER-2 specific immunity during treatment with trastuzumab and chemotherapy. Clin Cancer Res 13:5133-5143

50. Srivastava RM, Lee SC, Andrade Filho PA, Lord CA, Jie HB, Davidson HC, López-Albaitero A, Gibson SP, Gooding WE,
Ferrone S, Ferris RL (2013) Cetuximab-activated natural killer and dendritic cells collaborate to trigger tumor antigen-specific T-cell immunity in head and neck cancer patients. Clin Cancer Res 19:1858-1872

51. Deligne C, Milcent B, Josseaume N, Teillaud JL, Sibéril S (2017) Impact of depleting therapeutic monoclonal antibodies on the host adaptive immunity: a bonus or a malus? Front Immunol 8:950

52. Geiger R, Duhen T, Lanzavecchia A, Sallusto F (2009) Human naive and memory CD4 $+\mathrm{T}$ cell repertoires specific for naturally processed antigens analyzed using libraries of amplified $\mathrm{T}$ cells. J Exp Med 206:1525-1534

53. Hanley PJ, Melenhorst JJ, Nikiforow S, Scheinberg P, Blaney JW, Demmler-Harrison G, Cruz CR, Lam S, Krance RA, Leung KS, Martinez CA, Liu H, Douek DC, Heslop HE, Rooney CM, Shpall EJ, Barrett AJ, Rodgers JR, Bollard CM (2015) CMV-specific T cells generated from naïve $\mathrm{T}$ cells recognize atypical epitopes and may be protective in vivo. Sci Transl Med 7:285ra63

54. Melssen M, Slingluff CL Jr (2017) Vaccines targeting helper T cells for cancer immunotherapy. Curr Opin Immunol 47:85-92

Publisher's Note Springer Nature remains neutral with regard to jurisdictional claims in published maps and institutional affiliations.

\section{Affiliations}

\section{Benoit Milcent ${ }^{1} \cdot$ Nathalie Josseaume ${ }^{1} \cdot$ Quentin Riller $^{1} \cdot$ Ilenia Giglioli ${ }^{1} \cdot$ Emilia Rabia $^{1}$. Claire Deligne ${ }^{1}$. Jean-Baptiste Latouche ${ }^{2} \cdot$ Mohamad Hamieh $^{2}$. Alexandre Couture ${ }^{2}$. Olivier Toutirais ${ }^{3,4} \cdot$ Yu-Chun Lone ${ }^{5}$. Raphaël Jeger-Madiot ${ }^{6}$. Stéphanie Graff-Dubois ${ }^{6} \cdot$ Sandy Amorim $^{7} \cdot$ Pascale Loiseau $^{8,9,10}$ - Antoine Toubert ${ }^{8,9,10}$. Pauline Brice $^{7}$. Catherine Thieblemont ${ }^{7,11}$. Jean-Luc Teillaud ${ }^{1,12}$. Sophie Sibéril ${ }^{1,13}$ (D)}

1 Sorbonne Université, Sorbonne Paris Cité, Université Paris Descartes, Université Paris Diderot, Inserm UMRS 1138, "Cancer, Immune Control and Escape" Laboratory, Centre de Recherche des Cordeliers, Paris, France

2 Inserm U1245, Institute for Research and Innovation in Biomedicine (IRIB), Normandie University, Rouen University Hospital, Rouen, France

3 Unicaen, Inserm 1237, Physiopathology and Imaging of Neurological Disorders, Normandie University, Caen, France

4 French Blood Service (Etablissement Français du Sang, EFS), Caen, France

5 Inserm U1014, Hôpital Paul Brousse, Villejuif, France

6 Inserm U1135, CNRS ERL8255, Center for Immunology and Microbial Infection, Paris, France

7 APHP, Saint-Louis Hospital, Hemato-oncology, Diderot University, Sorbonne Paris Cité, Paris, France
8 Laboratoire d'Immunologie et Histocompatibilité, Hôpital Saint-Louis, Paris, France

9 Inserm UMR-S 1160, Paris, France

10 Institut Universitaire d'Hématologie, Université Paris Diderot-Paris 7, Paris, France

11 EA7324 Université Paris Descartes, Sorbonne Paris Cité, Paris, France

12 Present Address: Laboratory "Immune Microenvironment and Immunotherapy", Sorbonne Université UMRS 1135, INSERM U.1135, Centre d'Immunologie et des Maladies Infectieuses (CIMI), Paris, France

13 Cordeliers Research Center-Inserm UMR-S 1138, "Cancer, Immune Control and Escape" Laboratory, 15 rue de l'Ecole de Médecine, 75006 Paris, France 